\title{
A Model of Meaning of Work, Work Engagement, Organizational Commitment and Turnover Intention in Jakarta and Bali Hotel Employees
}

\author{
Nadya Karinadewi* and Fanny Martdianty
}

\author{
Faculty of Economics and Bsuiness, Universitas Indonesia, Indonesia
}

\begin{abstract}
The hospitality industry, especially the hotel sector, is one of the world's highest in staff turnover rate. This is also the case in Indonesia, where the hotel industry is rife with problems related to high staff turnover. In this paper, we explore how hotel employees view the meaning of their work and how it contributes to their work engagement, organizational commitment, and turnover intention. Based on the data collected from 406 hotel employees in Jakarta and Bali, a structural equation model (SEM) was used to examine if hotel employees' meaning of work influences their engagement with their work, commitment to the organization, and turnover intention. The results indicated that employees' meaning of work positively influenced work engagement, and work engagement positively influenced organizational commitment. Work engagement was found to be an indirect-only mediator in the relationship between meaning of work and organizational commitment. Additionally, organizational commitment was also found to negatively influenced turnover intention. As the first study of its kind in Indonesia, this paper provides an invaluable starting point for examining the dynamics of meaningful work with employee engagement, commitment, and turnover in Indonesian hotel employees.
\end{abstract}

Keywords: Meaning of Work; Work Engagement; Organizational Commitment; Turnover Intention; Hospitality; Hotel

\section{Introduction}

Globally, the hospitality industry employs 1 out of 10 workers (Langford, Weissenberg, \& Gasdia, 2019). However, this does not mean that the industry can retain its employees easily. In fact, the hospitality industry has one of the world's highest staff turnover rates (Langford, Weissenberg, \& Gasdia, 2019; Robinson, Kralj, Solnet, Goh, \& Callan, 2014). This is especially true for the hotel industry, where the high saturation of the industry leads employers to always compete with each other in order to get the workers they need. The high turnover rate is also partially due to employees experiencing a lot of pressure during interactions with guests (Karatepe, Uludag, Menevis, Hadzimehmedagic, \& Baddar, 2006; Karatepe \& Kilic, 2007). This is caused by the particular nature of the hospitality work, of which employees are obliged to deliver excellent service to their guests. The pressure often leads to heavy physical and emotional labor, especially in frontline workers who always have to display positive emotions in front of guests (Lam \& Chen, 2012).

Compared to workers from other industries, hotel employees are also more sensitive to financial compensation (Lam, Zhang, \& Baum, 2001). The hotel industry's remuneration budget increased significantly from $15 \%$ in the previous years to 25-30\% of their revenue in 2018 (Langford, Weissenberg, \& Gasdia, 2019). Coupled with the difficult working conditions and long hours, the relatively low income makes it difficult to retain employees. This is also the case for hotel management companies in Indonesia, where the high staff turnover rates often cause problems within the industry.

This makes it important for hotel management companies to start paying attention to other variables other than financial compensation when it comes to their employees. In particular, employers should ensure that employees attach good meaning to their work and consider that the hospitality work is appropriate for them. Several studies in the industry report that there is a significant link between the meaning of work and guest satisfaction (Chen, Yen, \& Tsai, 2014) and 
that it reduces the negative effect of long working hours and low wages Karatepe, Beirami, Bouzari, \& Safavi, 2014; Pizam, 2015). In general, the meaning of work increases competence, productivity, and organizational commitment (Ulrich \& Ulrich, 2010). Jung and Yoon (2016) stated that the relationship between meaning of work and organizational commitment is moderated by work engagement. May, Gilson, and Harter, (2004) found that the meaning of work is the strongest predictor of work engagement. Despite this, very little research has examined the meaning of work for employees in the hotel industry. This research aims to bridge the gap in the literature by determining the effect of meaning of work to Indonesian hotel employees' work engagement, organizational commitment, and turnover intention. The paper proceeds as follows. Literature review related to this research is explored in section 2 and the methodology is presented in section 3. Section 4 and 5 will discuss about the result of the study, and section 6 concludes the paper.

\section{Literature Review}

Turnover intentions are defined as an individual's willingness to change their job (Schyns, Torka, \& Gössling, 2007). It is the strongest predictor of employee turnover (Joo \& Park, 2010). The degree of compatibility between job seekers and the job's characteristics will decide the strength of turnover intentions (Allen, Bryant, \& Vardaman, 2010). In the hotel industry context, Lam, Lo, and Chan (2002) stated that even though most hotels are able to initially attract good candidates, they have difficulties in retaining them. Low organizational commitment and high turnover rates are constant problems a lot of hotels face. This, of course, led to another problem: low service quality. In response to this, Dimitrov (2012) stated that in hotel industry, work situations that are conducive to shaping meaningful work will lower hotel employees' intention to move.

What makes work meaningful for us? As something that is perceived by employees, the meaning of work is an important construct for organizations (Rosso, Dekas, \& Wrzesniewski, 2010; Jung \& Yoon, 2016). Steger, Dik, and Duffy (2012) define the meaning of work as an individual's interpretation of the significance and positive influence of their work in their life as a whole. The meaning of work develops in an individual through four sources: the self, others, the context, and spiritual life (Rosso, Dekas, \& Wrzesniewski, 2010). These four sources manifest into a coherent meaning of work through several mechanisms: authenticity, self-efficacy, self-esteem, purpose, belongingness, transcendence, and cultural/interpersonal sense making. Steger, Dik, and Duffy (2012) describe the meaning of work as consisting of three primary facets:

1. Positive meaning at work, or the subjective meaning of work for the employee.

2. Meaning-making through work, or how the employee's work contributes to their life's meaning.

3. Greater good motivation, or the way an employee interprets their work as contributing to the society at large. 


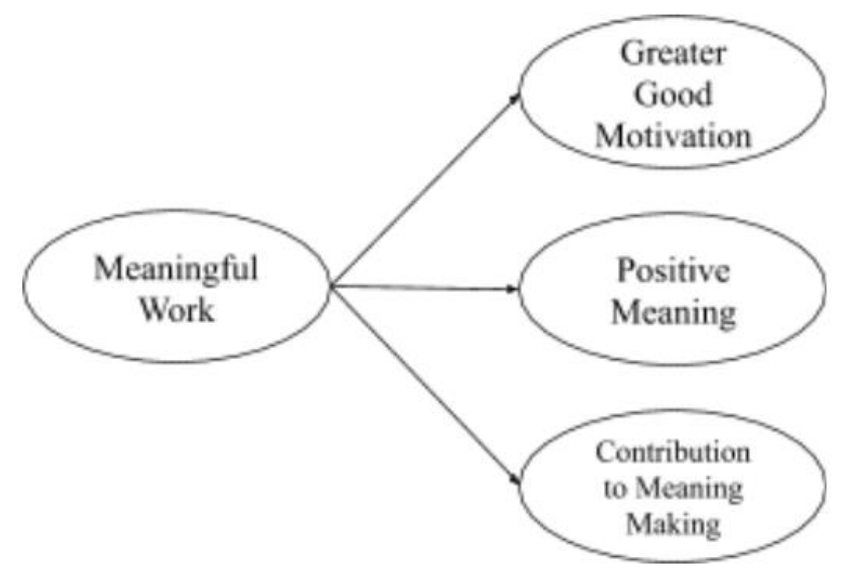

Fig. 1: Meaning of Work Model (Steger, Dik, \& Duffy, 2012)

Schaufeli, Martinez, Pinto, Salanova, and Bakker (2002) defines work engagement as a positive, fulfilling, work-related state of mind that is characterized by vigor, dedication, and absorption. Work engagement is a sustained cognitive and affective state; it is not just a temporary condition felt by employees at one point in time. Engaged employees are happier, spend more time doing their job, and more prepared to face challenges at work. There are three dimensions of work engagement: vigor, dedication, and absorption (Schaufeli, Salanova, González-Romá, \& Bakker, 2002).

Organizational commitment has been the subject of much research in the organizational context. Meyer and Allen (1991) defined organizational commitment as a psychological state that characterizes the employee's relationship with the organization and has implications for the decision to continue or discontinue membership in the organization. There are three components of organizational commitment: affective commitment, continuance commitment, and normative commitment. Affective commitment relates to the employee's emotional attachment, identification, and engagement with the organization. Continuance commitment relates to the employee's belief about the cost of leaving the organization. Normative commitment relates to the employee's sense of obligation to stay with the organization. All three components interact with one another, creating an interactive model that affects each other depending on each type's strength (Meyer and Allen, 1991).

\section{Research Methodology}

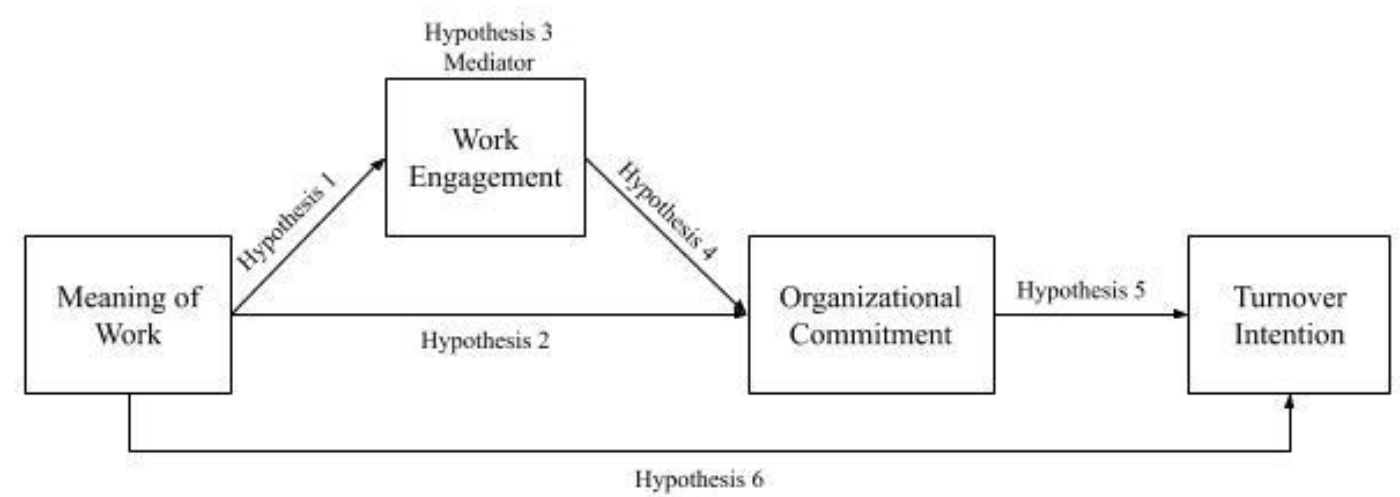

Fig. 2: A Proposed Model of Meaning of Work, Work Engagement, Organizational Commitment, and Turnover Intention

Figure 2 shows employees' meaning of work as the independent variable and work engagement as the mediating variable, with organizational commitment and turnover intention as the dependent variable. This paper examines the 
effects of hotel employees' meaning of work on work engagement (Hypothesis 1), organizational commitment (Hypothesis 2), and turnover intention (Hypothesis 6). This paper also explores the mediating role of work engagement on the relationships between meaning of work and organizational commitment (Hypothesis 3). It then investigates effects of work engagement on organizational commitment (Hypothesis 4) and organizational commitment on turnover intention (Hypothesis 5). As additional analysis, this paper will also explore the possible differences between results obtained from hotel employees in Jakarta and Bali, and between frontline and back of the house employees.

This paper uses a quantitative approach to examine the proposed model of meaning of work, work engagement, organizational commitment, and turnover intention. This empirical study will use primary data that will be collected through online questionnaires. The sample consisted of 406 hotel employees in Jakarta and Bali. The total number of hotels used in this study are 32 hotels, with 20 rated as two-star hotels and 12 as four-star hotels. The sample included hotel employees across all divisions, including frontline and back of the house employees.

Participants' demographic data, including age, job levels, job functions, and length of tenure will be collected. In regards to measurements, this study uses four questionnaires as research instruments. To measure meaning of work, Work and Meaning Inventory (Steger, Dik, \& Duffy, 2012) will be used, while to measure work engagement Utrecht Work Engagement Scale - 9 (Schaufeli, Bakker, \& Salanova, 2006) will be used. Organizational commitment will be measured using Organizational Commitment Questionnaire (Meyer \& Allen, 1997) and turnover intention using Turnover Intention Scale (Mobley, Horner, \& Hollingsworth, 1978).

To profile the participants' demographics, frequency analyses was performed. Data analysis in this study used the AMOS program. The Cronbach's Alpha method was used to analyze the reliability of the measurements. To test the validity of the hypothesis, this study used the structural equation model (SEM).

\section{Results}

The data used in this research is obtained from hotel employees who are based in Jakarta and Bali. A total of 406 participants is used as the sample, with 288 participants living in Jakarta (70.9\%) followed with 118 people from Bali $(29.1 \%)$. Based on the descriptive analysis on the data gathered from all participants, the mean data of meaning of work, work engagement, and organizational commitment are shown to be high. This is in contrast to turnover intention which is shown to be on the lower end. In regards to the main analysis of this paper, Table 1 shows the results of the research based on the structural equation model (SEM) used to analyze the data.

Table 1: Regression Weights

\begin{tabular}{|c|c|c|c|c|}
\hline Hypothesis & Latent Variable Relationship & Estimate & S.E. & P-value \\
\hline 1 & MP --> KK & 1.114 & 0.085 & $0.000^{*}$ \\
\hline 2 & MP --> KO & -0.098 & 0.21 & 0.64 \\
\hline 3 & MP --> KK --> KO & 1.332 & 0.308 & $0.004 *$ \\
\hline 4 & KK --> KO & 1.195 & 0.184 & $0.000^{*}$ \\
\hline 5 & KO --> IPK & -0.532 & 0.109 & $0.000^{*}$ \\
\hline 6 & MP --> IPK & -0.026 & 0.199 & 0.896 \\
\hline
\end{tabular}

1. Meaning of work positively affected the work engagement. This shows that employees with meaningful work tend to be more involved in their work. 
2. Work engagement fully mediated the relationship between meaning of work and organizational commitment.

3. Work engagement positively affected the organizational commitment. The higher an employee's work engagement, the higher their organizational commitment will be.

4. Organizational commitment negatively affected the turnover intention.

5. Meaning of work did not affect organizational commitment and turnover intention.

\section{Discussion}

This paper discusses the effect of hotel employees' meaning of work on their work engagement, organizational commitment, and turnover intention. Based on the results data analysis using structural equation model (SEM), this study found that the meaning of work had a significant positive effect on the work engagement of employees in Jakarta and Bali hotels. This finding aligned with the findings of previous studies (Chen, Yen, \& Tsai, 2014; Duffy, Autin, \& Bott, 2015; Jung \& Yoon, 2016) and showed that employees who perceived that their work was meaningful had higher work engagement. The results of this study also showed that employees' meaning of work positively affected their organizational commitment when work engagement acted as a full mediator in the relationship. This finding confirmed Jung and Yoon (2016) study where work engagement was also found to be mediating the relationship. However, the result of this study showed that work engagement fully mediated the relationship while Jung and Yoon (2016) found that it only partially mediated the relationship. Work engagement was also found to positively affect the organizational commitment. This result confirmed several studies on this topic in several industries (Hakenen, Bakker \& Schaufeli, 2006; Simpson, 2008). The result also confirmed Zopiatis, Constanti, and Theocharous' (2014) previous study, where they found a positive relationship between work engagement and affective and normative organizational commitment in hotel workers. Organizational commitment, in turn, negatively affected the turnover intention. This finding aligns with the results of previous studies, especially in the hotel sector of the hospitality industry (Alniacik, Alniaçik, Erat, \& Akçin, 2013; Gatling, Kang, \& Kim, 2016; Wasti, 2010).

\section{Conclusions}

In this paper, we have discussed the effect of Jakarta and Bali hotel employees' meaning of work on their work engagement, organizational commitment, and turnover intention. From the structural equation model (SEM), the results show that meaning of work positively affected work engagement. Work engagement positively affected organizational commitment and also fully mediated the relationship between meaning of work and organizational commitment. In turn, organizational commitment negatively affected turnover intention.

These findings have implications for the management in Indonesia hotel industry. To enhance employees' meaning of work, management should note that employees should be encouraged to have interest in their job through learning and development programs, through which the management is providing conditions where they are reminded of the meaning of their work. Leisure activities and socially-oriented programs should also be utilized to make sure that employees can develop vertical and horizontal relationships with their colleagues in the hotel. The learning and development programs implemented at the hotels should focus more on employee experience and ways to improve it for each employee. There are several limitations to this study. First, this study did not differentiate between the frontline and back of the house workers in hotels. Further study should consider a comparison between the results from these two job functions. Second, the results of this study are limited to a small segment of Indonesia hotel industry. Further research is advised to consider other sectors of Indonesia hospitality industry such as food and beverage, airlines, travel, or cruise.

\section{References}

Allen, D. G., Bryant, P. C., \& Vardaman, J. M. (2010). Retaining talent: Replacing misconceptions with evidence-based strategies. Academy of management Perspectives, 24(2), 48-64. 
Alniacik, E., Alniaçik, Ü., Erat, S., \& Akçin, K. (2013). Does person-organization fit moderate the effects of affective commitment and job satisfaction on turnover intentions? Procedia-Social and Behavioral Sciences, 99, $274-281$.

Chen, C.-Y., Yen, C.-H., \& Tsai, F. C. (2014). Job crafting and job engagement: The mediating role of person-job fit. International Journal of Hospitality Management, 37, 21-28.

Gatling, A., Kang, H. J. A., \& Kim, J. S. (2016). The effects of authentic leadership and organizational commitment on turnover intention. Leadership \& Organization Development Journal.

Joo, B. K. B., \& Park, S. (2010). Career satisfaction, organizational commitment, and turnover intention. Leadership \& Organization Development Journal.

Jung, H. S., \& Yoon, H. H. (2016). What does work meaning to hospitality employees? The effects of meaningful work on employees' organizational commitment: The mediating role of job engagement. International Journal of Hospitality Management, 53, 59-68.

Kang, H. J., Gatling, A., \& Kim, J. (2015). The impact of supervisory support on organizational commitment, career satisfaction, and turnover intention for hospitality frontline employees. Journal of Human Resources in Hospitality \& Tourism, 14(1), 68-89.

Karatepe, O. M., Beirami, E., Bouzari, M., \& Safavi, H. P. (2014). Does work engagement mediate the effects of challenge stressors on job outcomes? Evidence from the hotel industry. International Journal of Hospitality Management, 36, 14-22.

Karatepe, O. M., \& Kilic, H. (2007). Relationships of supervisor support and conflicts in the work-family interface with the selected job outcomes of frontline employees. Tourism management, 28(1), 238-252.

Karatepe, O. M., Uludag, O., Menevis, I., Hadzimehmedagic, L., \& Baddar, L. (2006). The effects of selected individual characteristics on frontline employee performance and job satisfaction. Tourism management, 27(4), 547560.

Lam, T., Zhang, H., \& Baum, T. (2001). An investigation of employees' job satisfaction: the case of hotels in Hong Kong. Tourism management, 22(2), 157-165.

Lam, W., \& Chen, Z. (2012). When I put on my service mask: Determinants and outcomes of emotional labor among hotel service providers according to affective event theory. International Journal of Hospitality Management, 31(1), 311 .

Langford, G., Weissenberg, A., \& Gasdia, M. (2019). US Travel and Hospitality Outlook. In: Deloitte.

Lu, A. C. C., \& Gursoy, D. (2016). Impact of job burnout on satisfaction and turnover intention: do generational differences matter? Journal of Hospitality \& Tourism Research, 40(2), 210-235.

May, D. R., Gilson, R. L., \& Harter, L. M. (2004). The psychological conditions of meaningfulness, safety and availability and the engagement of the human spirit at work. Journal of occupational and organizational psychology, 77(1), 11-37.

Meyer, J. P., \& Allen, N. J. (1991). A three-component conceptualization of organizational commitment. Human resource management review, 1(1), 61-89.

Meyer, J. P., \& Allen, N. J. (1997). Commitment in the workplace: Theory, research, and application: Sage.

Mobley, W. H., Horner, S. O., \& Hollingsworth, A. T. (1978). An evaluation of precursors of hospital employee turnover. Journal of Applied psychology, 63(4), 408.

Pizam, A. (2015). Is the foodservice industry composed of only low-paid and unskilled jobs? International Journal of Hospitality Management(50), 153-154.

Robinson, R. N., Kralj, A., Solnet, D. J., Goh, E., \& Callan, V. (2014). Thinking job embeddedness not turnover: Towards a better understanding of frontline hotel worker retention. International Journal of Hospitality Management, 36, 101-109.

Rosso, B. D., Dekas, K. H., \& Wrzesniewski, A. (2010). On the meaning of work: A theoretical integration and review. Research in organizational behavior, 30, 91-127.

Schaufeli, W. B., Bakker, A. B., \& Salanova, M. (2006). The measurement of work engagement with a short questionnaire: A cross-national study. Educational and psychological measurement, 66(4), 701-716.

Schaufeli, W. B., Martinez, I. M., Pinto, A. M., Salanova, M., \& Bakker, A. B. (2002). Burnout and engagement in university students: A cross-national study. Journal of cross-cultural psychology, 33(5), 464-481. 
Schaufeli, W. B., Salanova, M., González-Romá, V., \& Bakker, A. B. (2002). The measurement of engagement and burnout: A two sample confirmatory factor analytic approach. Journal of Happiness studies, 3(1), 71-92.

Schyns, B., Torka, N., \& Gössling, T. (2007). Turnover intention and preparedness for change. Career Development International.

Steger, M. F., Dik, B. J., \& Duffy, R. D. (2012). Measuring meaningful work: The work and meaning inventory (WAMI). Journal of career Assessment, 20(3), 322-337.

Ulrich, D., \& Ulrich, W. (2010). The why of work: Tata McGraw-Hill Education.

Wasti, S. A. (2003). Organizational commitment, turnover intentions and the influence of cultural values. Journal of occupational and organizational psychology, 76(3), 303-321.

Wells, M. (2018). Turnover And Retention Rates For Hotels And The Hospitality Industry. Daily Pay. 